\title{
Impact of Product Packaging Elements on Consumer Purchase Notion: A Study FMCG Items
}

\author{
Maloth Naresh Naik \\ Research scholar, \\ Dept. Business management, Osmania university \\ Dr. Rambabu Lavuri \\ Post Doctoral Fellow, \\ Dept. Business management, Osmania university
}

\begin{abstract}
The main intention of this paper is to investigate the impact of products packaging elements on the purchase behaviour of consumers and then analysis the consumers purchasing capability. The aim of this research is to study the elements of product packaging. This research paper seeks to examine the need to understand consumer purchase notion in order to correctly design product packing elements and to achieve the desired position in the minds of consumers. Companies in order to create the right packaging for their products, they must understand the consumer buying process and understand the impact of packaging elements as a variable that can influence the purchase decision of consumers. The prevailing research paper examine focuses on the impact of packaging elements on buy notion of customers with regard FMCG items, in which in the scope of study changed into limited to Hyderabad town. A shape questionnaire was used to degree the effect of packaging elements. With pattern size 825 respondents and examined thru descriptive information, chances, ANOVA, correlation and multiple regression analysis by means of the usage of SPSS 20.0 version. The end result of the look at showed that media Vehicles like TV, newspaper and magazine and net statistically considerable on purchasing patron in the direction of FMCG packaging. Followed by the product packaging elements have statistical significant on the purchase notion of consumers, but element like back ground of packaging is not statistically significant on the purchase notion.
\end{abstract}

Keywords: Packaging elements, Consumers, FMCG, Purchase notion, Background colour.

DOI: $10.7176 / \mathrm{EJBM} / 11-10-06$

Publication date: April $30^{\text {th }} 2019$

\section{Introduction}

Now, packaging has turn out to be itself a sales merchandising device for the corporations. The client's shopping for conduct additionally inspired by means of the packaging satisfactory, colour, wrapper, and other characteristics of packaging. Packaging is an entire bundle that will become a remaining promoting proposition, which stimulates impulse buying behavior. Packaging will increase income and marketplace percentage and decreases marketplace and promotional fees. Consistent with Rundh (2005) package deal appeals patron's attentiveness toward a positive brand, will increase its photograph, and stimulates purchaser's perceptions about product. Moreover, packaging conveys exceptional price to merchandise (Underwood, 2003; Silayoi, \& Speece, 2007), packaging works as an instrument for differentiation, and allows clients to decide the product from huge range of parallel products, packaging also stimulates patron's shopping for behavior (Wells, Farley \& Armstrong, 2007). Preceding researches show that there's no settlement on overall category of packaging cloth and bundle elements. There is also disagreement concerning the techniques of package impact on consumer's shopping for behavior choice. Several researchers try to have a look at all capacity factors of packaging and their impact on purchaser's buying selection (Butkeviciene, Stravinskiene, \& Rutelione, 2008), but others attention on distinct elements of packaging and their influence on client shopping conduct (Ampuero \& Vila, 2006; Madden, Hewett, \& Roth, M, 2000; Underwood, Klein, \& Burke, 2001; Bloch, 1995). Moreover, a few researchers discover the impact of packaging and its features on purchaser's entire purchase selection (Underwood, Klein, \& Burke, 2001), while, a few others - on every step of client's selection-making technique (Butkeviciene, Stravinskiene, \& Rutelione, 2008). Brand photo and advertisement have sturdy an impact on and big dating with patron's buying conduct. Human beings perceive the brand photo with high quality mindset. Look at depicted that teens in Gujranwala are extra conscious about their social repute, so that they choose branded merchandise and commercial impacts on their customer buying Behaviour definitely (Malik, Ghafoor, Iqbal, Ali, Hunbal, Noman, and Ahmed, 2013).

\section{Literature Review}

Packaging acts multidimensional capabilities. It offers expertise about the product and company, a technique to speak with customers and safeguard to the pleasant of product (Silayoi \& Speece, 2007). In line with Rita 
Kuvykaite1 (2009) to have a look at reveals the self-carrier and changing clients' way of life having the last impact on purchaser choice. Increase in impulse shopping for conduct labeling is also speaking to the purchaser. Saeed, Lodhi, Mukhtar, Hussain, Mahmood and Ahmad (2013), combine the logo photo, brand attachment and environmental consequences and their impact on purchaser purchase selection. (consequences) elaborates that emblem photo don't have a effective relation with buy decision, emblem attachment has a moderate superb relation with buy selection and environmental consequences but don't have a positive relation with buy selection (Ahmed \& Kazim, 2011).

The purchasers buy extra quantity of the products, after looking a nicely-classified product. Therefore, labeling impacts the patron shopping for behavior, however there are some different elements additionally, which affect the patron shopping for conduct (Saeed, Lodhi, Rauf, Rana, Mahmood \& Ahmed, 2013). In recent times, humans have become extra worried in the direction of green shopping because of a grown cognizance for environmental protection. Inexperienced buying is basically the act of buying environmental friendly products. The research model in this take a look at examines the effects of predictor variables (environmental situation, organizational green image and environmental expertise) upon criterion variable (inexperienced buy goal) with the moderating impact of perceived product rate and first-class (Underwood, 2003; Rettie \& Brewer, 2000; Barber, Almanza, \& Donovan, 2006). Adelina \& Morgan (2007) conclude that Packaging can be treated as one of the most valuable tool in this day's advertising communications; Packaging has a vital effect on customers shopping for conduct. The effect of packaging and its elements can impact the patron's buy selection (Ahmed et.al, 2014).

In keeping with Karbasivar \& Yarahmadi (2011), greater clothing impulse shopping for and promotional methods (cash cut-price) utilization among sample, in addition to in-save shape show (window display) has important function to encourage purchasers to shop for impulse. They can present complementary products to encourage patron to buy impulse. Also, sealers can boom clothing impulse shopping for with redecorating their stores in modern-day fashion and use appealing lights and colourings. The end result of the take a look at proves that there's a pivotal courting between window display, credit score card, promotional sports (discount, unfastened product) and customer impulse buying behaviour (Alice, 2006). In line with Erzsebet \& Zoltan (2007) each the qualitative and quantitative studies confirmed that respondents adopted similar threat reduction strategies of their purchase of infant care products. These studies investigated consumer perceptions and buying behaviour of baby care products. The consequences of the number one research showed those consumers' needs glad about the product in phrases of reliability and performance and packaging.

In keeping with Butkeviciene, Stravinskiene and A. Rutelione (2008), impulse buying is indeed an applicable component in CE retailing, for this reason justifying using sales packaging. But, optimization is still important. From a cheap and environmental attitude it is very steeply-priced to apply income packaging (with additional fabric use and transport extent) to products that don't want them, or to use them in an useless way. Saeed, Lodhi, Mukhtar, Hussain, Mahmood and Ahmad (2011), combine the emblem picture, brand attachment and environmental outcomes and their impact on client buy decision. Elaborates that emblem image don't have an effective relation with purchase selection, brand attachment has a moderate superb relation with purchase decision and environmental consequences however don't have a high quality relation with purchase choice (Ahmed, Arif \& Meenai, 2012).

\section{Objectives of the Study}

Following are the primary objective of the study

- To study the types of Media vehicles that influence consumer purchase behaviour towards the packaging of FMCG products.

- To examine the impact of product packaging elements influence on consumer purchase behaviour towards FMCG products

\section{Hypothesis of the Study}

Following are the hypothesis of the study

- HO H $_{1}$ There is no significant influence of media vehicles on consumer purchase behaviour towards packaging of FMCG products.

- $\mathrm{HO}_{2}$ : There is no significant impact of Product Packaging Elements on Consumer Purchase behaviour.

\section{Scope of the Study}

From the scene various investigations of the literature review and framed conceptualization created by the scholars. They are focusing mainly on the bundling terms and their performance. Just a few studies ware done on bundling in the Indian context with the FMCG sector. Only some of the studies said about the spirited strategies on the role of the bundling in the changed competitive situation of the market in the Indian markets. The present study is mainly focusing on the impact of product packaging, strategies of packaging which have been 
implemented by the FMCG sector. And what are the strategies applied by the Marketer to influence of the consumer purchase behaviour with the product packaging? And also helpful to see the impact of strategies of product packaging on the consumer purchase notion towards the FMCG sector.

\section{Significance of the Concept}

With the end goal of the present examination, bundling is be conceptualized as "Bundling includes advancing, securing and upgrading the item". Bundling advances the items by pulling into consideration. The principal limited time assignment of the bundle is to pull in consideration. Since discernment is particular, the bundle ought to be intended to draw in consideration in an outwardly jumbled condition. It ought to likewise educate the purchaser about the item. Bundles add to moment acknowledgment of organization or brand and induce the purchaser to get it. The bundle imparts more to the buyer than the real item, at the purpose of procurement where the customer chooses. The bundle must pass on the privilege of enthusiastic characteristics about the item that it fills the customer's need. Packaging having a greater role to influence the consumers by the greater image, it contains the ideal information, characteristics, and advantages of the product. Product packaging is one of the strategies of every organization, it is the internal strategy that increasing sales flow by attracting more customers. Because of most of the customers purchasing and judging the product by its bundling pattern before buying the product.

\section{Methodology}

- Research Design: Descriptive research

- Sources of data: The study is concerned with the consumer perception and product packaging strategies, based on that source of the data collected from Primary source of data is collected from the respondents through structured questionnaire and interviews. It was in order to collect data on the product packaging strategies which affect on consumer purchase perception. Secondary data is collected from various Journals, Periodicals such as Magazines, Business newspapers, and from subject related books and websites.

- Sample Size: 825 Respondents From Hyderabad City

Base on the Cochran's formula (infinity population), the sample size selected is 825 . The sample size selected from the sample area i.e Hyderabad city, Telangana state. For mountain accuracy, reliability and validity of the data very small and large size samples are avoided. Because of the very small size sample having an inappropriate representation of the total sample area and large size sample have very difficult to handling all the process and managing data in a proper way.

Cochran's formula for infinity population:

$$
\mathrm{SS}=\frac{\mathrm{Z}^{2} * \mathrm{P}(\mathrm{P}-1)}{\mathrm{e}^{2}}
$$

$\mathrm{SS}=$ Sample Size

$\mathrm{Z}=\mathrm{Z}$-Value/ Confidence Level @ 95\% level i.e 1.96

$\mathrm{P}=\%$ of population picking choice from the total population $(40 \%=0.4)$

$\mathrm{e}=$ Confidence interval/ Marginal error

$$
\mathrm{SS}=\frac{1.96^{2} * 0.4 * 0.6}{-0 .-------}
$$

$$
\mathrm{SS}=368.79(369)
$$

- Data collections methods: Data has been collected using structure questionnaire through customer survey method and personal interview of consumers with help of Convenience sampling method, Statistical tools like ANOVAs, Correlation and Multiple Regression using SPSS 20.0 has been used.

General profile of Respondents: The frequency distribution of demographic variables is presented in the following table. 
Table-1: Profile of Respondents

\begin{tabular}{|c|c|c|c|}
\hline Particulars & Classification & No of Responses & Percentage \\
\hline \multirow{5}{*}{ Age } & Below 20 Years & 180 & 21.8 \\
\hline & 21-30 Years & 234 & 28.4 \\
\hline & $31-40$ Years & 228 & 27.6 \\
\hline & 41-50 Years & 137 & 16.6 \\
\hline & 51 and Above & 46 & 5.6 \\
\hline \multirow{2}{*}{ Gender } & Male & 582 & 70.5 \\
\hline & Female & 243 & 29.5 \\
\hline \multirow{5}{*}{ Education } & $\mathrm{SSC}$ & 77 & 9.3 \\
\hline & Intermediate & 100 & 12.1 \\
\hline & Degree & 234 & 28.4 \\
\hline & pg degree & 273 & 33.1 \\
\hline & PG and above & 141 & 17.1 \\
\hline \multirow{5}{*}{ Occupation } & Govt Employee & 252 & 30.5 \\
\hline & Private Employee & 299 & 36.2 \\
\hline & Business & 98 & 11.9 \\
\hline & Home Maker & 84 & 10.2 \\
\hline & Student & 92 & 11.2 \\
\hline \multirow{5}{*}{$\begin{array}{l}\text { Monthly } \\
\text { income (in } \\
\text { rupees) }\end{array}$} & below 20,000 & 86 & 10.4 \\
\hline & $20,001-30,000$ & 125 & 15.2 \\
\hline & $30.001-40,000$ & 318 & 38.5 \\
\hline & $40,001-50,000$ & 203 & 24.6 \\
\hline & 50,001 and above & 93 & 11.3 \\
\hline Total & & $n=825$ & $100 \%$ \\
\hline
\end{tabular}

- Age: More than $28.4 \%$ candidates belongs the age group of 21-30 years and above, and $27.6 \%$, $21.8 \%, 16.6 \%$ and $5.6 \%$ by the age of $31-40$ years, below 20 years, $41-50$ years and 51 and above years respectively.

- Gender: From the above desk it is evident that $70.5 \%$ of the whole respondents belong to male accompanied by $29.5 \%$ through female respective.

- Education: It is found from above table, that extra than $33.1 \%$ of the respondents belongs to pg, and followed with $28.4 \%, 17.1 \%, 12.1 \%$, and $9.3 \%$ belongs to degree, pg and above, intermediate and SSC respectively.

- Occupation: It is evident from above table, that more than $36.2 \%$ of the respondents working as private employee, and it are observed that $30.5 \%, 11.9 \%, 11.2 \%$ and $10.2 \%$ working as govt employee, Business, Student and Homemaker respectively.

- Income in rupees: $38.5 \%$ of family have an income between 30,001-40,000 followed by $24.6 \%$, $15.2 \%, 11.3 \%$ and $10.4 \%$ with the income of 40,001-50,000, 20,001-30,000, and 50,001 and above and below 20,000 have family income level of respondents. 


\section{Conceptual Framework}

Image: 1

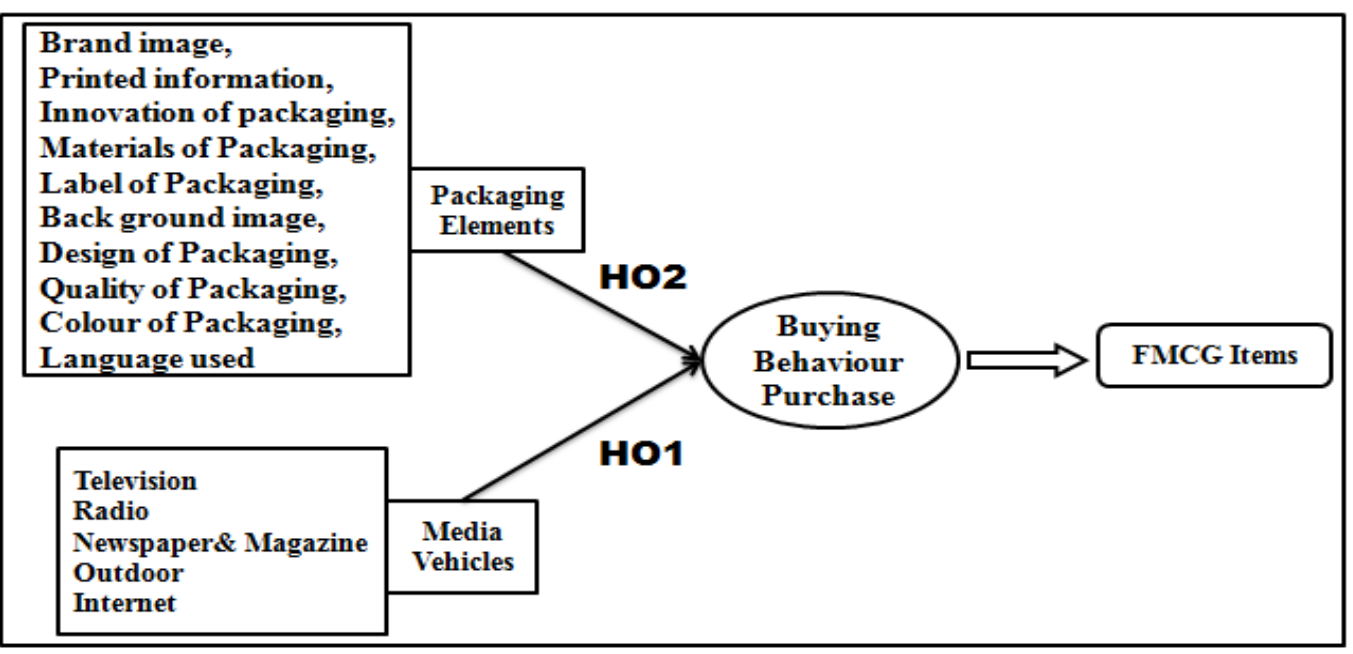

\section{Consequences and Discussions}

Table 2: scale construction

\begin{tabular}{lcc}
\hline Questionnaire & Items & Alpha \\
\hline Media vehicles influence & 4 Items & 0.761 \\
Packaging elements & 10 Items & 0.883 \\
\hline
\end{tabular}

This confirms the validity and reliability of present studies paper. Major variables: Media exposure and product packaging techniques on client notion are considered. Alpha values were calculated one after the other for each the variables to test for the reliability and validity of the destiny take a look at. The Cronbach's alpha values for Media exposure and product packaging strategies are observed to be 0.761 and 0.883 .

HO${ }_{1}$ : There is no significant influence of media exposure on consumer purchase behaviour towards packaging of FMCG products.

Table - 3: ANOVAs

\begin{tabular}{|c|c|c|c|c|c|c|}
\hline & & Sum of squares & Df & Mean Square & $\mathrm{F}$ & Sig. \\
\hline \multirow{3}{*}{ TV } & Between Groups & 13.817 & 17 & .813 & .858 & \multirow{3}{*}{.005} \\
\hline & Within Groups & 764.381 & 807 & .947 & & \\
\hline & Total & 778.199 & 824 & & & \\
\hline \multirow{3}{*}{ Radio } & Between Groups & 20.409 & 17 & 1.201 & $1 \mathrm{c} .276$ & \multirow{3}{*}{.200} \\
\hline & Within Groups & 759.113 & 807 & .941 & & \\
\hline & Total & 779.522 & 824 & & & \\
\hline \multirow{3}{*}{ Newspaper and Magazine } & Between Groups & 17.800 & 17 & 1.047 & 2.227 & \multirow{3}{*}{.003} \\
\hline & Within Groups & 379.380 & 807 & .470 & & \\
\hline & Total & 397.181 & 824 & & & \\
\hline \multirow{3}{*}{ Outdoor } & Between Groups & 17.117 & 17 & 1.007 & 1.389 & \multirow{3}{*}{.004} \\
\hline & Within Groups & 585.126 & 807 & .725 & & \\
\hline & Total & 602.242 & 824 & & & \\
\hline \multirow{3}{*}{ Internet } & Between Groups & 16.293 & 17 & .958 & .980 & \multirow{3}{*}{.009} \\
\hline & Within Groups & 789.424 & 807 & .978 & & \\
\hline & Total & 805.716 & 824 & & & \\
\hline
\end{tabular}

The above table reveals that any mean difference between the two sets of variables like media exposure and consumer purchase behaviour, and it indicated that 764.381 is the between-group variation in the group of TV as a source of information and consumer purchase behaviour and 764.381 is the within-group variation of TV and Purchase behaviour of consumers. The box also reveals that F-distribution .858, Followed by, the level of significance is .05 is less than 0.05 . Through this, the Alternative hypothesis accepted and the null hypothesis is rejected. The result shows that there is a significant influence of TV exposure on consumer purchasing FMCG products. And followed with media exposure channels like Radio, Newspaper, and Magazine, Outdoor, and Internet of between groups variations are 20.409, 17.800, 17.117, 16.293 and their variance in Within group value is $759.113,379.380,585.126,789.424$. F-Statistic values are 1.276, 2.227, 1.389 and .980 followed with 
significant level are $0.200,0.003,0.004$ and 0.009 , all are less than 0.05 except 0.200 . Finally, the results indicate that the Alternative hypothesis of a statement accepted while rejected the Null hypothesis. So the media exposure channels like newspaper and magazine, Outdoor and internet significantly impact on the consumer purchase behaviour, but radio (0.200) does not significantly impact on consumer purchase behaviour with respect of Packaging of FMCG products.

$\mathrm{HO}_{2}$ : There is no significant impact of Product Packaging Elements on Consumer Purchase behaviour.

Table- 4: ANOVAs

\begin{tabular}{|c|c|c|c|c|c|c|}
\hline & & Sum of Squares & $\mathrm{df}$ & Mean Square & $\mathrm{F}$ & Sig. \\
\hline \multirow{3}{*}{ Colour of Packaging (E1) } & Between Groups & 2.934 & 4 & .733 & 11.945 & .000 \\
\hline & Within Groups & 50.353 & 820 & .061 & & \\
\hline & Total & 53.287 & 824 & & & \\
\hline \multirow{3}{*}{ Back ground image of Packaging(E2) } & Between Groups & 27.922 & 17 & 1.642 & 1.610 & .056 \\
\hline & Within Groups & 823.525 & 807 & 1.020 & & \\
\hline & Total & 851.447 & 824 & & & \\
\hline \multirow{3}{*}{ Materials of Packaging(E3) } & Between Groups & 17.052 & 17 & 1.003 & 1.763 & .009 \\
\hline & Within Groups & 459.049 & 807 & .569 & & \\
\hline & Total & 476.102 & 824 & & & \\
\hline \multirow{3}{*}{$\begin{array}{l}\text { Printed information } \\
\text { (E4) }\end{array}$} & Between Groups & 8.680 & 17 & .511 & .623 & .000 \\
\hline & Within Groups & 660.957 & 807 & .819 & & \\
\hline & Total & 669.636 & 824 & & & \\
\hline \multirow{3}{*}{ Innovation of packaging(E5) } & Between Groups & 9.279 & 17 & .546 & .455 & .001 \\
\hline & Within Groups & 968.170 & 807 & 1.200 & & \\
\hline & Total & 977.450 & 824 & & & \\
\hline \multirow{3}{*}{ Label of Packaging(E6) } & Between Groups & 23.390 & 17 & 1.376 & 1.376 & .001 \\
\hline & Within Groups & 806.930 & 807 & 1.000 & & \\
\hline & Total & 830.320 & 824 & & & \\
\hline \multirow{3}{*}{ Quality of Packaging(E7) } & Between Groups & 12.640 & 17 & .744 & .447 & .002 \\
\hline & Within Groups & 1341.825 & 807 & 1.663 & & \\
\hline & Total & 1354.465 & 824 & & & \\
\hline \multirow{3}{*}{ Design of Packaging(E8) } & Between Groups & 16.380 & 17 & .964 & 1.153 & .005 \\
\hline & Within Groups & 674.536 & 807 & .836 & & \\
\hline & Total & 690.916 & 824 & & & \\
\hline \multirow{3}{*}{ Language used on Packaging(E9) } & Between Groups & 26.080 & 17 & 1.534 & 1.263 & .000 \\
\hline & Within Groups & 980.461 & 807 & 1.215 & & \\
\hline & Total & 1006.541 & 824 & & & \\
\hline \multirow{3}{*}{$\begin{array}{l}\text { Brand image on the Packaging } \\
\text { (E10) }\end{array}$} & Between Groups & 21.348 & 17 & 1.256 & 1.425 & .000 \\
\hline & Within Groups & 710.975 & 807 & .881 & & \\
\hline & Total & 732.322 & 824 & & & \\
\hline
\end{tabular}

In order to understand whether there is any significant impact of Packaging elements of products with respect to consumer purchase Behaviour. It is observed that from the above table, packaging element like Colour of packaging (E1) and consumer purchase behaviour difference in the sum of the squares and 21.344 is the variation in the between the group and, this value is small because of the mean values are closed in between the groups. 876.251 is the variation within the group and the value of F-distribution is 1.156. Finally, the level of significance value is 0.002 , which is smaller than 0.05 . So the results indicate that the null hypothesis can be rejected. So Colour of Packaging (E1) impacts on Consumer purchase behaviour with respect to FMCG products. And followed with packaging elements like Background image of Packaging(E2),Materials of Packaging(E3), Printed information(E4), Innovation of packaging(E5), Label of Packaging(E6), Quality of Packaging(E7), Design of Packaging(E8), Language used on Packaging(E9), Brand image on the Packaging (E10) of between groups variations are 27.922, 17.052, 8.680, 9.279, 23.390, 12.640, 16.380, 26.080 and 21.348, their Within group variations are $823.525,459.049,660.957,968.170,806.930,1341.825,674.536,980.461,710.975$. FStatistic values are $1.610,1.763, .623, .455,1.376, .447,1.153,1.263$ and 1.425 . Followed with significant level are $0.56,0.009,0.000,0.001,0.001,0.002,0.005,0.000$, and 0.000 . These respected significance values are smaller than 0.05 . Finally, table values indicate that the alternative hypothesis accepted and the null hypothesis rejected on the bases of the results. The Packaging elements dimensions are impacted on consumer purchase behaviour towards FMCG products, but packaging element like Background image of Packaging (E2) is not a 
significant impact on consumer purchase behaviour, because of its significance level is 0.056 and it is more than 0.05 .

Correlations between Packaging Elements variable with Purchase behaviour of the Final consumers: Table - 5: Descriptive Statistics

\begin{tabular}{|l|c|c|c|}
\hline & Mean & Std. Deviation & $\mathrm{N}$ \\
\hline Colour of Packaging (E1) & 3.12 & 1.044 & 825 \\
\hline Back ground image of Packaging (E2) & 3.26 & 1.017 & 825 \\
\hline Materials of Packaging(E3) & 2.57 & .760 & 825 \\
\hline Printed information (E4) & 3.33 & .901 & 825 \\
\hline Innovation of packaging (E5) & 3.70 & 1.089 & 825 \\
\hline Label of Packaging (E6) & 3.72 & 1.004 & 825 \\
\hline Quality of Packaging (E7) & 2.97 & 1.282 & 825 \\
\hline Design of Packaging (E8) & 2.71 & .916 & 825 \\
\hline Language used on Packaging (E9) & 3.09 & 1.105 & 825 \\
\hline Brand image on the Packaging(E10) & 3.66 & .943 & 825 \\
\hline Consumer Purchase Behaviour & 3.7671 & .35144 & 825 \\
\hline
\end{tabular}

The mean values of Packaging elements variables like Colour of Packaging(E1), Back ground image of Packaging(E2), Materials of Packaging(E3), Printed information(E4), Innovation of packaging(E5), Label of Packaging(E6), Quality of Packaging(E7), Design of Packaging(E8), Language used on Packaging(E9), Brand image on the Packaging (E10) and consumer purchase behaviour are found to be 3.12, 3.26, 2.57, 3.33, 3.70, $3.72,2.97,2.71,3.09,3.66$ and 3.7671 with standard deviations of $1.044,1.017, .760, .901,1.089,1.004$, $1.282, .916,1.105, .943$, and .35144 respectively.

\begin{tabular}{|c|c|c|}
\hline S.No & Packaging elements & Pearson Correlations \\
\hline 1 & Colour of Packaging & $.542^{* *}$ \\
\hline 2 & Back ground image of Packaging & $.405^{* *}$ \\
\hline 3 & Materials of Packaging & $.357^{* *}$ \\
\hline 4 & Printed information & $.612^{* *}$ \\
\hline 5 & Innovation of packaging & $.384^{* *}$ \\
\hline 6 & Label of Packaging & $.311^{* *}$ \\
\hline 7 & Quality of Packaging & $.513^{* *}$ \\
\hline 8 & Design of Packaging & $.473^{* *}$ \\
\hline 9 & Language used on Packaging & $.312^{* *}$ \\
\hline 10 & Brand image on the Packaging & $.443^{* *}$ \\
\hline
\end{tabular}

** Correlation is significant at the 0.001 level (2-tailed)

The Elements of the packaging like Colour of Packaging $\left(\mathrm{r}=.542^{* *}\right)$, Printed information $\left(\mathrm{r}=.612^{* *}\right)$ and Quality of Packaging $\left(\mathrm{r}=.513^{* *}\right)$ are having strongly correlations with the Consumer purchase behaviour. Whereas, elements like Label of Packaging $\left(\mathrm{r}=.311^{* *}\right)$, Language used on Packaging $\left(\mathrm{r}=.312^{* *}\right)$ having weak correlation with consumer purchase behaviour.

Multiple regressions between Product Packaging Elements with purchase behaviour of Consumers.

\begin{tabular}{|l|l|r|r|r|}
\hline \multicolumn{5}{|c|}{ Table 7: Model Summary } \\
\hline Model & R & R Square & Adjusted R Square & Std. Error of the Estimate \\
\hline 1 & $.492^{\mathrm{a}}$ & .242 & .233 & .22277 \\
\hline
\end{tabular}

a. Predictors: (Constant), Brand image on the Packaging, Printed information, Innovation of packaging, Materials of Packaging, Label of Packaging, Back ground image of Packaging, Design of Packaging, Quality of Packaging, Colour of Packaging, Language used on Packaging

$\mathrm{R}^{2}$ value reveals that the amount of difference in the dependent variables, and it is explained by the independent variables like Brand image on the Packaging, Printed information, Innovation of packaging, Materials of Packaging, Label of Packaging, Back ground image of Packaging, Design of Packaging, Quality of Packaging, Colour of Packaging, Language used on Packaging. Followed by the $\mathrm{R}^{2}$ value is the found that 0.242 , it implies the meaning by $24.2 \%$ variation of difference explained by the predictors / independent variables. This is the total strength of association between dependent variables and independent / predictors. 
IISE

\begin{tabular}{|l|l|c|c|c|c|c|}
\hline \multicolumn{7}{|c|}{ Table 8: ANOVA } \\
\hline \multicolumn{2}{|c|}{ Model } & Sum of Squares & Df & Mean Square & F & Sig. \\
\hline \multirow{3}{*}{1} & Regression & 12.892 & 10 & 1.289 & 25.980 & $.000^{\mathrm{b}}$ \\
\cline { 2 - 7 } & Residual & 40.394 & 814 & .050 & & \\
\cline { 2 - 7 } & Total & 53.287 & 824 & & & \\
\hline
\end{tabular}

a. Dependent Variable: Consumer purchase behaviour

b. Predictors: (Constant), Brand image on the Packaging, Printed information, Innovation of packaging, Materials of Packaging, Label of Packaging, Back ground image of Packaging, Design of Packaging, Quality of Packaging, Colour of Packaging, Language used on Packaging

Ho: There is no significant variation caused by predictors on Consumer Purchase Behavior.

The above box reveal that the value of F-distribution is statistically significant, therefore the following statement i.e. the null hypothesis rejected and the alternative hypothesis. So the result implies that there is a variation of difference of variation caused by the independent variables on the dependent variables.

Table 9: Coefficients ${ }^{\mathrm{a}}$

\begin{tabular}{|c|c|c|c|c|c|}
\hline \multirow{2}{*}{ Model } & \multicolumn{2}{|c|}{ Unstandardized Coefficients } & \multirow{2}{*}{\begin{tabular}{|c|} 
Standardized Coefficients \\
Beta
\end{tabular}} & \multirow{2}{*}{$\mathrm{T}$} & \multirow{2}{*}{ Sig. } \\
\hline & B & Std. Error & & & \\
\hline (Constant) & 3.895 & .119 & & 27.301 & .000 \\
\hline Colour of Packaging & .079 & .023 & .224 & 6.238 & .000 \\
\hline Back ground image of Packaging & -.097 & .033 & -.101 & -2.852 & .104 \\
\hline Materials of Packaging & -.076 & .027 & -.053 & -1.520 & .009 \\
\hline Printed information & -.087 & .035 & -.067 & -1.802 & .002 \\
\hline Innovation of packaging & -.047 & .021 & -.019 & -.601 & .548 \\
\hline Label of Packaging & .072 & .032 & .115 & 3.438 & .001 \\
\hline Quality of Packaging & -.084 & .022 & -.083 & -2.066 & .009 \\
\hline Design of Packaging & .140 & .048 & .347 & 8.008 & .000 \\
\hline Language used on Packaging & -.059 & .034 & -.026 & -1.609 & .003 \\
\hline Brand image on the Packaging & .083 & .015 & .058 & 1.568 & .007 \\
\hline
\end{tabular}

a. Dependent Variable: Consumer purchase behaviour

The above table reveal that results of t-statistics values at the 2 tailed p-values with testing statistically significant with Zero, by the help of Alpha with 0.05 values: Followed with the table indicates that the results of $\mathrm{t}$ - values and $\mathrm{p}$-values. The value of ' $\mathrm{t}$ ' for all the predictors like Colour of Packaging (6.238), Back ground image of Packaging (-2.852), Materials of Packaging (-1.520), Printed information (-1.802), Innovation of packaging (.601), Label of Packaging (3.438), Quality of Packaging (-2.066), Design of Packaging (8.008), Language used on Packaging (-1.609) and Brand image on the Packaging (1.568) and p-values of the respected predictors are $0.000, .009, .009, .001, .009,000, .003$ and .007 values are statistically significant and because of these values are smaller than the alpha value (0.005). Whereas Back ground image of Packaging (0.104) and Innovation of packaging $(0.548) \mathrm{p}$-values are more than 0.005 , these are not statistically significant because their values are more than alpha value.

\section{Managerial Implications}

The entrepreneurs ought to come with modern and precise packaging while they may be launching new merchandise in the market. Mass Media play an important function to persuade more on clients purchase behaviour. So this main factor, marketers preserve excessive great of video, audio, clarity of message about product packaging. If the commercial enterprise or manufactures are retaining proper elements of packaging with cautious examination, it facilitates to construct and generate the extra effective income the best one way is there to get greater proper results in an powerful manner, it occurs by way of constructing the powerful techniques planning of packaging of their respective product segments.

\section{Limitations of the Research}

No research is without certain limitation specifically in the case of surveys conducted through structured questionnaires or personal interviews. So, the outcomes of the present study are limited or geographically responses may vary. By giving attention to these apparent reasons, we can see the following limitations: The sample is drawn from Hyderabad city; therefore, the sample may not represent the whole population. Hence, the limitation of generalization will be there. A sample size of 825 respondents has been selected in and around Hyderabad city as related to the universe, bias respondents responses, deficiency of published / unpublished literature on Product packaging strategies and time restriction could be some limitations. This study is not consider total FMCG product packaging, Since few categories in FMCG products are considered, like Personal care products (Cosmetics), Dairy products (Milk, Ghee, Ice cream), Food products (Biscuits, Bread, Cakes) and 
Beverages (Soft drinks \& Energy drinks) and only to evaluate the packaging strategies impact on the purchase behaviour of final selected respondents. Personal bias of respondents while answering the question may have skewed the results slightly, although an effort has been made to verify the results through all sorts of quantitative and qualitative.

\section{Conclusions}

This study attempted to explore the Impact of product packaging elements on consumer purchasing behaviour and try to comprehend its influence in their decision making by attempting to consolidate the various view points to reach at a conclusion which can better explain the notion of rationality and at the same time the act of consumption. For the past days, packaging was viewed just as a box/container or outer covering, but packaging has various tasks to playing at this point. As for the consequences confirmed that media exposure like TV, radio, newspaper and magazine and internet statistically sizable on patron belief in the direction of FMCG packaging, besides Radio. And packaging elements have advantageous effect at the patron towards purchase belief. But back ground of the packaging not influence on buying of behaviour of consumers. Ultimately, the researcher concluded that the entrepreneurs observed greater effective product packaging elements and techniques in market for attracting and rendering new and existed customers for increasing enterprise and product marketplace proportion.

\section{References}

Adelina Broadbridge, and Henry Morgan. (2007). Consumer buying behaviour and perception toward retail brand baby products.

Ahmad, N., Billoo, M., Lakhan, A. (2012). Effect of Product Packaging in Consumer Buying Decision. Journal of Business Strategies, 6(2), PP. 1993-5765.

Ahmed, R.R., Ahmad, N., Parmar, V., Khoso, I. 2014. Role of Packaging and Labelling on Pakistani Consumers Purchase Decision, European Scientific Journal, 10 (16): 464-473.

Ahmed, R.R., Arif, A.A., Meenai, Y.A., 2012. New Product development: Strategy \& implementation mechanism based on Primary \& Secondary data Research, Interdisciplinary Journal of Contemporary Research Business, 4 (6): 1034-1046.

Ahmed, R.R., Kazim, S.S., 2011. New Product development: Strategy \& implementation mechanism for Copy testing, European Journal of Scientific Research, 60 (4), 221-240

Alice, L., 2006, the power of packaging, United States of America, pp. 186-216.

Ampuero, O., \& Vila, N., 2006. Consumer perceptions of product packaging. Journal of Consumer Marketing, 23(2), 100-112.

Barber, N., Almanza, B.A., \& Donovan, J.R., 2006. Motivational factors of gender, income and age on selecting a bottle of wine. International Journal of wine marketing, 18 (3), 218-232.

Bloch, P.H., 1995. Seeking the ideal form: product design and consumer response. Journal of Marketing, 59, (July), 16-29.

Butkeviciene, V., Stravinskiene, J., \& Rutelione, A., 2008. 'Impact of consumer package communication on consumer decision making process', Inzinerine Ekonomika-Engineering Economics (1), pp. 57-65.

Erzsebet Hetesi1 - Zoltan Veres, 2007. An empirical investigation on loyalty. The case of packaging industry.

Karbasivar, A. and Yarahmadi, H., 2011. Evaluating Effective Factors on Consumer Impulse Buying Behavior. Asian Journal of Business Management Studies 2 (4): 174-181.

Madden, T. J., Hewett, K., \& Roth, M. S., 2000. Managing images in different cultures: A cross-national study of color meanings and preferences. Journal of International Marketing, 8(4), 90-107.

Maiksteniene, K., and Auruskeviciene, V., 2008. 'Manufacturer and retailer brand acceptance under different levels of purchase involvement', Inzinerine Ekonomika-Engineering Economics (1), pp. 90-96.

Malik, E.M., Ghafoor, M.M., Iqbal, K.H., Ali, Q., Hunbal, H., Noman, M., and Ahmed, B., 2013. Impact of Brand Image and Advertisement on Consumer Buying Behavior. World Applied Sciences Journal 23 (1):117-122.

Rettie, R., \& Brewer, C., 2000. The verbal and visual components of package design. Journal of Product Brand Management, $9(1), 56-70$.

Rita Kuvykaite, A.D., 2009. Impact of Package Elements on Consumer's Purchase Decision. Economics and Management, pp: 441-458.

Rundh, B., 2005. The multi-faceted dimension of packaging. British Food Journal, 107 (9), 670-684.

Saeed, R., Lodhi, R.N., Mukhtar, A.M.J., Hussain, S., Mahmood, Z., and Ahmad, M., 2011. Factors Affecting Consumer Purchase Decision in Clothing Industry of Sahiwal, Pakistan. World Applied Sciences Journal 24 (7): 844-849.

Saeed, R., Lodhi, R.N., Rauf, A., Rana, M.I., Mahmood, Z., and Ahmed, N., 2013, Impact of Labelling on Customer Buying Behavior in Sahiwal, Pakistan. World Applied Sciences Journal 24 (9): 1250-1254. 
Silayoi, P., \& Speece, M., 2007. The importance of packaging attributes: a conjoint analysis approach. European Journal of Marketing, 41 (11/12), 1495-1517.

Underwood, R. L., 2003. The communicative power of product packaging: creating brand identity via lived and mediated experience. Journal of Marketing Theory and Practice, winter, 62-76

Underwood, R. L., 2003. The communicative power of product packaging: creating brand identity via lived and mediated experience. Journal of Marketing Theory and Practice, Winter, 62-76

Underwood, R.L., Klein, N.M., \& Burke, R.R., 2001. Packaging communication: attentional effects of product imagery. Journal of Product \& Brand Management, 10 (7), 403-422.

Wells, L.E., Farley, H., \& Armstrong, G.A., 2007. The importance of packaging design for own-label food brands. International Journal of Retail \& Distribution Management, 35 (9), 677-690. 